\title{
Teaching NeuroImages: Japanese encephalitis
}

Bingjun Zhang, MD, Siyuan Liao, MD, Yu Yang, PhD, and Zhengqi Lu, PhD

Neurology ${ }^{\circledR}$ 2018;91:e2031-e2032. doi:10.1212/WNL.0000000000006553

Figure MRI findings in Japanese encephalitis
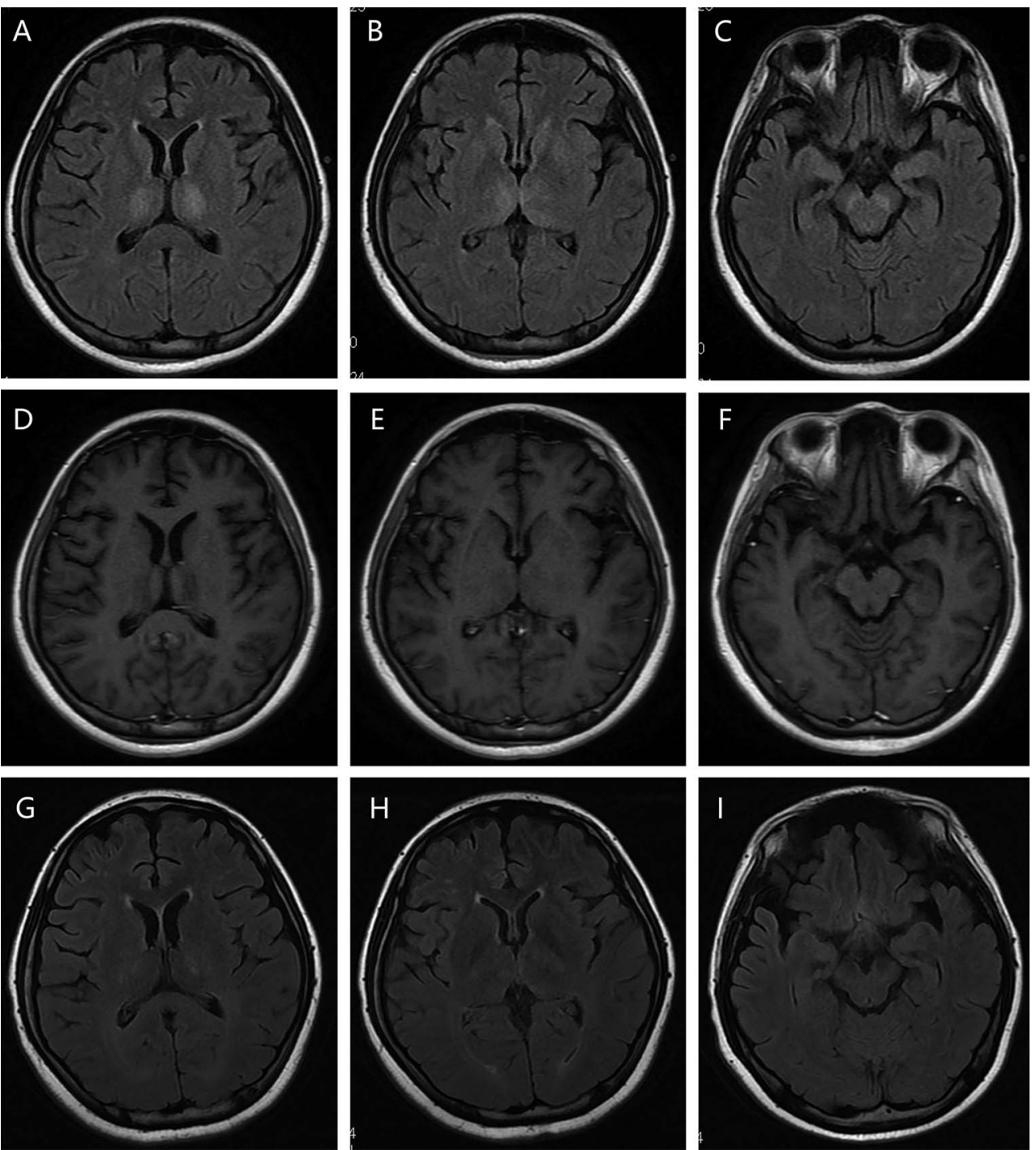

\section{Correspondence}

Dr. Lu

Izqzssy@gmail.com

\section{MORE ONLINE}

\section{$\rightarrow$ Teaching slides}

links.lww.com/WNL/ A742

(A-C) MRI brain axial T2 fluid-attenuated inversion recovery: symmetric hyperintensity in the thalami and substantia nigra. (D-F) MRI brain axial T1+ gadolinium: no contrast enhancement. (G-I) MRI brain axial T2 fluid-attenuated inversion recovery: The lesions had improved substantially after 3 months supportive care.

A 20-year-old woman presented with 3 days' history of fever and deteriorating consciousness. Physical examination showed positive Kerning sign. Brain MRI revealed hyperintensity involving bilateral thalami and substantia nigra (figure). Although CSF tests

From the Department of Neurology, the Third Affiliated Hospital of Sun Yat-sen University, Guangzhou, China.

Go to Neurology.org/N for full disclosures. Funding information and disclosures deemed relevant by the authors, if any, are provided at the end of the article. 
for white blood cells, protein, glucose, chlorine, and TORCH antibodies were normal, Japanese encephalitis (JE) virus immunoglobulin $M$ antibody was positive. Therefore, a diagnosis of JE was made. The patient recovered from coma, and brain lesions were disappearing after 3 months supportive care (figure). As a common human viral encephalitis in the world, JE is usually very severe with high case-fatality rate. ${ }^{1}$ Symmetric thalami and substantia nigra involvement are characteristic in JE. ${ }^{2}$

\section{Author contributions}

B. Zhang: study concept and design, acquisition and analysis of data, preparation of manuscript including figures. S. Liao: data analysis and interpretation. Y. Yang: acquisition and preparation of data. Z. Lu: study concept and design, data acquisition and interpretation, critical revision.

\section{Study funding}

No targeted funding reported.

\section{Disclosure}

The authors report no disclosures relevant to the manuscript. Go to Neurology.org/N for full disclosures.

\section{References}

1. Misra UK, Kalita J. Overview: Japanese encephalitis. Prog Neurobiol 2010;91:108-120.

2. Dung NM, Turtle L, Chong WK, et al. An evaluation of the usefulness of neuroimaging for the diagnosis of Japanese encephalitis. J Neurol 2009;256 2052-2060. 


\title{
Neurology
}

\author{
Teaching NeuroImages: Japanese encephalitis \\ Bingjun Zhang, Siyuan Liao, Yu Yang, et al. \\ Neurology 2018;91;e2031-e2032 \\ DOI 10.1212/WNL.0000000000006553
}

This information is current as of November 19, 2018

\section{Updated Information \& Services}

References

Subspecialty Collections

Permissions \& Licensing

Reprints including high resolution figures, can be found at: http://n.neurology.org/content/91/21/e2031.full

This article cites 2 articles, 0 of which you can access for free at: http://n.neurology.org/content/91/21/e2031.full\#ref-list-1

This article, along with others on similar topics, appears in the following collection(s):

Meningitis

http://n.neurology.org/cgi/collection/meningitis MRI

http://n.neurology.org/cgi/collection/mri

Viral infections

http://n.neurology.org/cgi/collection/viral_infections

Information about reproducing this article in parts (figures,tables) or in its entirety can be found online at:

http://www.neurology.org/about/about_the_journal\#permissions

Information about ordering reprints can be found online:

http://n.neurology.org/subscribers/advertise

Neurology ${ }^{\circledR}$ is the official journal of the American Academy of Neurology. Published continuously since 1951, it is now a weekly with 48 issues per year. Copyright () 2018 American Academy of Neurology. All rights reserved. Print ISSN: 0028-3878. Online ISSN: 1526-632X.

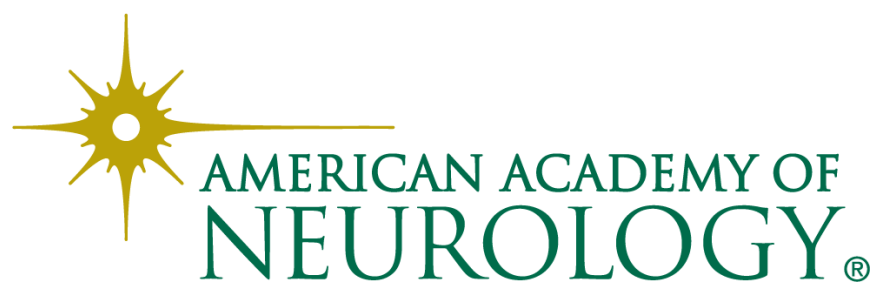

